\title{
USAGE OF YOU TUBE- BASED VIDEOS IN LEARNING DAILY ENGLISH CONVERSATION FOR CHILDREN AT ASRAMA YATIM MIZAN AMANAH, SALIHARA, PASAR MINGGU, SOUTH JAKARTA
}

\author{
Evi Jovita Putri \\ Universitas Nasional, Jakarta \\ 085274042432 \\ evijovitaputri@gmail.com \\ Gilang Ilham Agustinus \\ Universitas Nasional, Jakarta \\ 081228526912 \\ Gilanghhh20@gmail.com \\ Intan Kusuma Wardhani \\ Universitas Nasional, Jakarta \\ 089631635124 \\ schezalia@gmail.com
}

Received April 13, 2020, Revised June11, 2020, Approved June 18, 2020

\begin{abstract}
This research aims to analyze the effectiveness of YouTube-based videos as a media in learning daily English conversation for children and to identify factors affecting learning daily English conversation for children by using YouTube-based videos as a media. To obtain the aims, this research uses six children whose ages vary from ten to twelve years old lived in Asrama Yatim Mizan Amanah located at Jalan Salihara, Pasar Minggu, South Jakarta as the source of data. Descriptive qualitative method is applied as the research design. In collecting data, the researchers gather the result of learning activities in pre-tests, treatments, and post-tests. Meanwhile, in analyzing the data, the researchers compare the children's pre-test score with their post-test score to see the development of learning which show their competence before and after being treated. in this case, the research is focused on two topics, Greeting and Introduction in English. The children are introduced some expressions of greeting and introduction in English children by using YouTube-based videos, then some roleplays or conversation containing expressions of greeting and introduction are shown to the children by watching together YouTube-based videos. The last, the children are asked to recognize and practice the expression of greeting and introduction in English. The result shows that the usage of YouTube based video as a media in learning daily English conversation for children is considered effective. Four out of six children are able to memorize new expressions of both greeting and introduction in English, whereas the two other children remains stagnant after learning using YouTube based videos. It is found that there are factors that affect learning English for children by using this media, they are; personality, motivation and attitude, intelligent, learners' belief, and personality. The most influential factors affecting learning are motivation and attitude. The successful children have these factors stronger rather than the stagnant children. Based on the result, the effectiveness in learning English using YouTube-based videos will be stronger if it is supported by an interactive and conducive learning atmosphere. The learning atmosphere should be considered to achieve a stronger speaking English proficiency.
\end{abstract}

Key words: YouTube based-videos, language learning, daily English conversation

ABSTRAK
Penelitian ini ditujukan untuk menganalisis keefektifan penggunaan video berbasis YouTube sebagai media dalam
belajar percakapan bahasa Inggris sehari-hari pada anak-anak dan untuk mengidentifikasi faktor yang
mempengaruhi pembelajaran percakapan bahasa Inggris sehari-hari pada anak-anak yang menggunakan video


berbasis YouTube. Untuk mencapai tujuan tersebut, penelitian ini menjadikan enam orang anak berumur sepuluh hingga dua belas tahun yang tinggal di Asrama Yatim Mizan Amanah Jalan Salihara, Pasar Minggu, Jakarta Selatan sebagai sumber data. Penelitian ini menggunakan metode descriptive qualitative. Disini, proses pengumpulan data meliputi pengumpulan hasil pre-tests, treatment, dan post-test. Sementara itu, proses analisis data dilakukan dengan cara membandingkan skor pre-test dengan skor post-test pembelajar untuk melihat perkembangan pembelajaran yang menunjukkan perkembangan anak-anak sebelum dan sesudah pembelajaran. Penelitian difokuskan pada dua topik pembelajaran yaitu sapaan dan perkenalan bahasa Inggris. Dalam hal ini anak-anak diajak mengenal ekspresi sapaan dan perkenalan dalam Bahasa Inggris melalui video yang ada pada YouTube. Kemudian menonton beberapa simulasi dari perilaku menyapa dan berkenalan dalam Bahasa Inggris juga melalui video You-Tube. Pada tahap terakhir, para pembelajar ini diminta untuk berlatih mengingat dan mempraktekkan ungkapan sapaan dan perkenalan dalam Bahasa Inggris Hasil penelitian menunjukkan bahwa penggunaan video berbasis YouTube sebagai media belajar percakapan bahasa Inggris sehari-hari adalah efektif. Empat dari 6 anak mampu mengingat kosakata sapaan dan perkenalan yang baru secara signifikan setelah belajar menggunakan media video berbasis You Tube, meskipun ada 2 anak yang tidak mengalami peningkatan. Ada beberapa faktor yang memengaruhi pembelajaran pada anak-anak tersebut diantaranya kepribadian, motivasi dan sikap, kecerdasan, dan keyakinan. Faktor yang paling berpengaruh pada pembelajaran adalah motivasi dan sikap. Anak-anak yang mengalami peningkatan belajar yang pesat memiliki faktor motivasi dan sikap yang lebih kuat dibanding anak-anak yang tidak mengalami peningkatan. Berdasarkan hasil tersebut, keefektifan dalam belajar percakapan Bahasa Inggris sehari-hari menggunakan video YouTube menjadi lebih besar jika didukung oleh atmosfer belajar yang interaktif dan kondusif. Hal ini mesti diperhatikan guna mencapai kemampuan Bahasa Inggris lisan yang lebih baik.

Kata Kunci: Video YouTube, Pembelajaran Bahasa, Percakapan dasar dalam Bahasa Inggris.

\section{INTRODUCTION}

\section{Background}

Indonesian learners commonly get a problem in learning English as their foreign language. Most of Indonesian learners had learned English since they were at the first year in elementary school. It is continuously taught until their final formal education in senior high school. Even, some of them has been studying it at the university level. Unfortunately, they commonly do not have a strong active English or it can be categorized as a passive skill. It sounds like an irony to the fact that they learn English not only for one or two years but twelve years. Some of them can write well, but they cannot speak, and vice versa. A recent news posted by Wijaya on IDN Times says that among Southeast Asia countries, Singapore is the only country to get the highest position sitting on the $5^{\text {th }}$ rank. While we-Indonesians-have to sincerely accept the $61^{\text {st }}$ rank on the list. (IDN Times, 2019). Other than that, the recent suggestion rising from Indonesian Teachers Association (Ikatan Guru Indonesia) in a meeting with newly-inaugurated Indonesian Education Minister, Nadiem Makarim on November that English learning in Indonesia will be focused more on conversation, not grammar (Kompasiana, 2019). That means later Indonesian students will focus on sharpening speaking skills which currently is their weakness. This urges us to find out an effective media to be used in learning. 
Jurnal Pujangga Volume 6, Nomor 1, Juni 2020

ISSN P 2443-1478

ISSN E 2443-148

The learning media in this research is YouTube-based videos containing some materials of daily English conversation and focused on greetings and introduction. This involvement of learning media is assumed to give better results for children during the process of learning. Asyar (2012) states that learning medium can be understood as anything that convey or channel messages from a planned source, so that a conducive learning environment occurs where the learner may carry out the learning process efficiently and effectively. In addition, Kemp (1985) explains that a video could present information, describe a process, and appropriately teach skills, shorten and develop time, influence attitudes, and can be reproduced. Thus, the researchers decide to take videos from YouTube because it has been a popular useful technology nowadays, Many Indonesian people spend most of their spare times on YouTube to watch many videos about movie, news, food, beauty, travelling or games. This media actually can be a source of learning, too. Therefore, the researchers assume that learning daily English conversation using YouTube-based videos is an effective media.

This study is applied to the children because learning foreign language in early age is assumed as the best way to achieve an active English-speaking skill. It is supported by Kosasih cited in Nufauziah (2013), the earlier children learn foreign languages, the easier it will be for them to understand. Moreover, children as learners have different factors affecting learning English. According to Lightbown and Spada cited in Firdaus (2017), the factors affecting learning are intelligence, aptitude, personality, motivation and attitudes, learners' beliefs, age of acquisition, and learners' preference. Thus, this research also concerns to the factors affecting learning daily English conversation for children, especially by using YouTube- based videos because knowing the factors supporting learning English and finding the factors disturbing the learning process will help us to solve the problem in practicing English speaking.

Furthermore, this study is supported by two previous studies. The first study comes from Panje et.al (2016) finds that the use of video as the method of learning is effective. The result shows an increase in the students' study result. It can be seen on how the students only receive $5 \%$ for their percentage of graduation, but after they are taught with the video, it increases to $85 \%$. Another study is conducted by Riti (2014) She says that the use of video as the method of learning Horverstehen is more effective than the conventional method with the percentage of effectiveness comes out $9,5 \%$ as well. Th previous studies help the researchers to believe that this research can be done as well as its purposes. 
Jurnal Pujangga Volume 6, Nomor 1, Juni 2020

ISSN P 2443-1478

ISSN E 2443-148

\section{Formulation of the Problem}

1. How is effectiveness of watching You Tube-based videos in learning daily English Conversation for children found at Asrama Yatim Mizan, Salihara, Pasar Minggu, South Jakarta?

2. What factors affecting learning daily English Conversation for children by using You Tube-based videos are found at Asrama Yatim Mizan, Salihara, Pasar Minggu, South Jakarta?

\section{Purposes of the Research}

1. To find out effectiveness of watching You Tube-based videos in learning daily English Conversation for children at Asrama Yatim Mizan Amanah, Salihara, Pasar Minggu, South Jakarta.

2. To analyze factors affecting learning daily English Conversation for children by using You Tube-based videos found at Asrama Yatim Mizan Amanah, Salihara, Pasar Minggu, South Jakarta.

\section{Review of the Related Literature}

\section{Second Language Learning}

There are two different terms; language learning and language acquiring. Those are two different terms, even though both words have a quite similar meaning of 'getting'.

According to Krashen, "Language acquisition is a subconscious process; language acquires are not usually aware of the fact that they are acquiring language, but are only aware of the fact that they are using the language for communication. On the other hand, language learning is the conscious one. Language learners know the rules, being aware of them, and being able to talk about them." (Krashen, 1982:10)

\section{Learners' factors}

Lightbown \& Spada (1993) cited in Firdaus (2017) makes a list of factors affected language learners as follow:

\section{a. Intelligence}

Some studies said that intelligence passed through verbal IQ tests can be a powerful factor when participating in learning related to analysis and rule learning. 
However, intelligence seems to play a less important role in classrooms where instruction is more focused on communication and interaction. Not everything can be done through IQ tests, because there are many people are lacking in academics but succeed in second language learning.

\section{b. Aptitude}

There are two aptitude tests namely the Modern Language Aptitude Test (MLAT) and Pimsleur Language Aptitude Test (PLAB). Both tests have the view that aptitude consists of various types of abilities, such as 1) the ability to identify and memorize new sound, 2) the ability to understand the function of particular words in sentences, 3) the ability to figure out grammatical rules from language samples, 4) memory for new words.

\section{c. Personality}

A number of personalities are proposed as factors that influence language learning. Many studies that measure the same personality traits produce different results. Others have found that many successful language learners do not get high scores on measures of extroversion. Personality studies show that personality variables may be the main factor only in conversational skills, not in acquiring literacy skills.

\section{d. Motivation and Attitudes}

Motivation in second language learning is a complex phenomenon that can be defined in two factors: the communicative needs of students and their attitude towards to the second language community. If students need to speak a second language in a variety of situations, they will be motivated to gain proficiency in it. And also if they have a good attitude towards to the speakers they will have more contact with them. Motivated students are students who actively participate in class. Crookes and Schmidt (1991) reported an increased level of motivation for students related to the pedagogical practices. Included among these are; 1) motivating student into the lesson (notes made by the teacher about upcoming activities to increase student interest), 2) varying the lesson, tasks, and materials: varying lessons, assignments, and materials can increase student motivation and prevent students from being bored, 3) using co-operative rather than competitive goals: requires every student to work together in solving problems. This can increase student confidence. They can also recognize their respective roles in a group.

\section{e. Language Preferences}

The term 'learning style' has been used to describe an individual natural, habitual, and preferred way of absorbing, processing, and retaining new information and skills. 
People who can't learn something until they see it are called visual learners. People who only need to hear once or twice before they know it are called aural learners. People who need to add physical movements during learning are called kinesthetic learners.

\section{f. Learner Beliefs}

Things that can influence the kind of strategies to learn new material is how their learning style or their beliefs about how language is learned. Teachers can use information to help learners multiply their learning strategies and thus develop them with greater language learning.

\section{g. Age of Acquisition}

Developments in the brain affect the nature of language acquisition. According to this view, language learning that occurs after the end of the critical period may not be based on innate biological structures that are believed to contribute to mastery of the first language or mastery of a second language in children. Instead older learners rely on the same general learning abilities that they use to learn other types of skills or information.

\section{METHODOLOGY OF THE RESEARCH}

Six children aged 10 up to 12 years old who live in Asrama Yatim Mizan Amanah - a sort of dormitory or house for orphans-located in Pasar Minggu, South Jakarta are used as the source of data. These children live together there but they go to different schools. So, they have learned English before which is obtained from different school. Meanwhile, the data of this research is children's achievement or result in learning daily English conversation by using You Tube-based videos as its media learning.

To conduct the research, there are several steps should be provided in collecting and analyzing data. The collecting data itself involves several steps. The first is preparation. This preparation is divided into some points; first, selecting some representative videos in You Tube which contain expressions of greeting and introduction in English; second, preparing materials for pre-test and post-test to the children to measure their English competence before and after treatment; third, having a visit to the children's dormitory as an introduction between researchers and learners; last, recording necessarily process of learning from the first day until the last day of collecting data process.

The second to fourth step is focused on the first learning topic, greeting in English. First is giving out a pre-test on the first learning topic, greetings in English. The pre-test is conducted 
Jurnal Pujangga Volume 6, Nomor 1, Juni 2020

ISSN P 2443-1478

ISSN E 2443-148

to measure the children's competence before being learned by using YouTube-based videos. The type of the test conducted is an oral test. The researchers ask the children whether they have already known English greeting expressions and what each expression means. Then, it is giving treatment related to learning topic, greetings in English. In giving treatment, the researchers are inspired by three period lesson. Seguin cited in Widya et.al (2018) mentions that third period lesson can be divided into three different sections, which are; 1) Introduction, 2) Recognition, and 3) Recall. In introduction, the children are asked whether they have ever learned daily English conversation, children play with English greeting expression videos, and let the children watch carefully until it ends. In recognition, the children watch the videos again with further explanation from the researchers like what the meanings of expressions are and when we should use them. Then in the recall section, the children are asked if they still remember and recognize the greeting expression watched from the videos, then they have to mention them as far as they remembered. Last, it is giving out a post-test. The researchers call the children to face the researchers one by one. All greeting expressions that they have learned are pronounced by the researchers. If it is said in English, they have to figure out their meanings in Indonesian. Vice versa, if it is said in Indonesian, they have to figure out their meanings in English.

Moreover, the fifth step to seventh step is concerning to the second topic, introduction in English. The fifth step itself is giving out a pre-test related the second learning topic, introduction in English. The goal of this pre-test is same as the first topic's pre-test which is conducted to measure the children's competence before being treated with the lessons. The type of the test is also an oral test. The researchers ask the students if they have already known introduction expressions and could use them in introducing themselves. The sixth step is giving treatment to the children related to the second topic, introduction in English. As the same way as the first topic, three period lessons are used to conduct the learning process. In introduction, the children are asked whether they have ever known how to introduce themselves in English, children play with English introduction videos like what expression could be used to introduce them, and let the children watch carefully until it ends. In recognition, the children watch the videos again with further explanation on every part of expressions in introducing oneself from the researchers. Lastly, for the recall, the children are asked whether they remember how to introduce themselves in English. In addition, the researchers distribute sheets of paper to the children on which are written English introduction expressions with blanks that they have to fill with their own biodata_for example, 'my name is____ ' , 'I was born in_____ , 'I live in ___ '. The children have to fill those with their own self information. Then, a mini game is played to 
Jurnal Pujangga Volume 6, Nomor 1, Juni 2020

ISSN P 2443-1478

ISSN E 2443-148

make them relax. There is no certain rules except the students along with the researchers have to gather in circle, and then we have a marker to be passed to each of us while singing a song. Whoever gets the marker - even the researchers - when the music stops have to introduce her or himself. The seventh step is giving out a post-test related to the second topic. Here, the researchers with the children gather in one big circle. Each of the children is told to stand up and introduce themselves in English using any expressions they remember from the learning process. Sometimes one or two expressions are lost but they have to figure out themselves. If they are totally blank, it is allowed to have a glance on the papers they have filled in before, but their scores are not added. Finally, the last step is scoring the pre-test and post-test results of both topics. The results of pre-test and post-test describe the development of learning English daily conversation for children by using YouTube-based videos.

In analyzing data, the researchers analyze the data which have been collected from the learning process with some steps, first, re-watch videos of the learning process to identify the factors affecting learning process. Second, the results of pre-test and post-test are compared to see the children's learning development before and after being treated with the YouTube-based videos. Third, analyze factors affecting the learning process.

\section{RESEARCH FINDING AND DISCUSSION}

Based on the study conducted at Asrama Yatim Mizan Amanah South Jakarta, the usage of YouTube-based videos as a media in learning daily English conversation to the six children aged 10 to 12 years old is effective. It means that the children mostly have significant enhancements of competence after being treated by YouTube-based videos. Four out of six children rapidly improve their English-speaking skill, while the rests are seen to remain the same.

It can be seen on data (1), by comparing her first and second learning result, it illustrates that she has significant development. At the first learning topic, she gets the highest score of the pre-test; it is nine out of fifteen. Her pronunciation of each greeting is quite good. She can mention nine expressions well, such as; 'hi', 'hello', 'good morning', 'good afternoon', 'good evening', 'good night', 'how are you?', 'nice to meet you', and 'goodbye'. The researchers are actually impressed of Luna's personality at the first visit. She is caught to have a distance with her friends, making herself busy reading a book. After talking with her, the researchers can say that Luna has a great intelligence although She has a quiet personality same as all of her friends. 
Jurnal Pujangga Volume 6, Nomor 1, Juni 2020

ISSN P 2443-1478

ISSN E 2443-148

In addition, the six children are very quiet people, they do not want to speak until the researchers take some tricks to get them speak out. The interesting point is this child is pretty different. She shows a good deal of interest in learning English. During the treatment, she watches the video carefully. She even takes notes of what are said in the video. Therefore, in the post-test, she successfully adds up her score into thirteen. It means that she almost memorizes all the materials because the maximum score is fifteen.

Furthermore, at the second learning topic, She also tends to look having enhancement of competence. She gets five in the pre-test, she can mention what her name is, how old she is, where she lives, where she comes from and what her hobby is, while in her post-test she can increase it twice as many as pre-test score. She can tell about 'my favorite subject', 'my favorite color', 'my friends call me', 'my favorite food', and 'I have a friend, her name is'. Based on that improvement, it can be said that learning daily English conversation by using YouTube-based videos is helpful. It is also illustrated by other children's improvement. These two tables describe the children's learning results by using YouTube-based videos.

\begin{tabular}{|l|l|l|l|}
\hline \multicolumn{4}{|l|}{$1^{\text {st }}$ TOPIC, GREETING } \\
\hline No Data & Name & \multicolumn{2}{|c|}{ score } \\
\hline & & Pre-test & Post-test \\
\hline 1 & Luna & 9 & 13 \\
\hline 2 & Zara & 4 & 8 \\
\hline 3 & Aulia & 4 & 10 \\
\hline 4 & Rindi & 2 & 9 \\
\hline 5 & Desi & 3 & 4 \\
\hline 6 & Ilma & 4 & 4 \\
\hline
\end{tabular}

\begin{tabular}{|l|l|l|l|}
\hline \multicolumn{3}{|l|}{$2^{\text {nd }}$ TOPIC, INTRODUCTION } \\
\hline $\begin{array}{l}\text { No } \\
\text { Data }\end{array}$ & Name & \multicolumn{2}{|c|}{ score } \\
\hline & & Pre-test & Pre-test \\
\hline 1 & Luna & 5 & 10 \\
\hline 2 & Zara & 4 & 9 \\
\hline 3 & Aulia & 3 & 6 \\
\hline 4 & Rindi & 1 & 8 \\
\hline 5 & Desi & 4 & 5 \\
\hline 6 & Ilma & 3 & 4 \\
\hline
\end{tabular}


As stated before, there are a few children who remain stagnant, having no significance enhancement; they are seen on data (5) and (6). Both of them are very quiet and pretty much same each other. When the researchers first meet with them, they do not want to talk until the researchers persuade them to talk, unlike their other friends - who have significant increasing in their competence. Actually, at first time all the children do not want to open themselves to speak up, and then they start to be brave, put aside their quiet personality to learn. It is quite different with data (5) and (6). They seem keeping a distance with the lesson. As the result- related to the table of the $1^{\text {st }}$ topic — data (5) gets three for her pre-test score and four in her post-test, while data (6) gets four in her pre-test and post-test. Moreover, at the $2^{\text {nd }}$ topic, Data (5) manages to get four in the pre-test and five in the post-test, while data (6), gets three in the pre-test and make it into four in the post-test.

Based on the data, factors affecting learning daily English conversation by using YouTube-based videos are mostly motivation and attitude, then followed by learner's belief, personality and intelligent. If the children pay attention well to the lesson, their skills will improve throughout the learning process. The children who have significant improvement after being treated by YouTube-based videos have motivation and attitude stronger rather than the children who remain stagnant after being treated too. It is seen on data (1), (2), (3), and (4).

The researchers do not place personality as the most influential factor affecting learning but identify motivation and attitude as the most influential factor affecting learning. It is caused by fact that the children basically have similar personality. At first time all of them is very quiet. They keep a distance with the strangers. They who have low self-confidence do not want to open themselves to speak up. However, after being motivated, some of them start to be brave, put aside their quiet personality for the sake of learning English. It can be said that a high motivation can give a good impact to the learning. Then, it also increases the learner's belief to achieve the learning English well. It is demonstrated by learning process of data (1), (2), (3), and (4). Besides that, one's intelligence also plays a role. Like a child in data (1) who has a big effort in learning. When others only watch the videos, she insists to take notes on hers' own so that she could memorize better rather than the others. Her intelligence is viewed that her pre-test are always above the average. 
Jurnal Pujangga Volume 6, Nomor 1, Juni 2020

ISSN P 2443-1478

ISSN E 2443-148

On the contrary, lack of motivation and attitude become the most significantly factors that disturbing learning English. It is explained by the case of children who remain stagnant after being treated, such as Data (5) and Data (6). During the treatment, these two children do not seem enjoy. They who are not interested in the lesson repeatedly take their eyes off the videos to look at the other sides. Even, they assume that English is difficult to learn since the beginning. Therefore, their low motivation and attitude give impact to a degradation of their belief and intelligence, even personality.

In addition, the effectiveness in learning English using YouTube-based videos will be stronger if it is supported by an interactive learning atmosphere. It is found that the learning atmosphere should be considered to give better impact to the learning process. The researchers manage to liven up the atmosphere of learning. Lower the tense during learning will give impact the better results. To build this atmosphere, the teachers are also asked to be more creative in order to avoid the boredom in the learning class. It is seen on the treatment process where a mini game is played to make children relax. Moreover, considering the learners' characters indeed create the better situation of learning process. Knowing learner's characters will help teachers to guide the learning process. It makes learners enjoy the teacher and learning. It is illustrated on the preparation of collecting data, teacher and class are adjusted to the children's character. Here, children at Asrama Yatim Mizan Amanah basically are taught to keep distance between people of opposite sex. Thus, atmosphere of learning should be adjusted to the value or norm or culture that learners believe in. Furthermore, YouTube-based videos as the learning media should be suitable and enjoyable with the learners' age. The researchers use videos which are acted by children. So, the videos become familiar with them. Finally, the further explanations about the video are also necessary. The researchers do not let the children watch the videos only, but actively ask whether they understand or not. The researchers interactively discuss about the videos and give them further explanations about what they watch. So, between teacher and learners need to create an interactive discussion about the lesson.

\section{CONCLUSION}

The researchers conclude that learning daily English conversation by using YouTube based videos is effective. The children mostly have significant enhancements of competence after being treated by YouTube-based videos. Four out of six children rapidly improved their English-speaking skill although there are a few of them seem stagnant. It is affected by some factors, they are; motivation and attitude, intelligent, learners' belief, and personality. 
Nevertheless, the most influential factors affecting learning are motivation and attitude. The successful children have these two factors stronger rather than the stagnant children. As long as they are willing to learn, as long as they have motivation and good attitudes during the learning process, it is believed that the learners will get the effectiveness of YouTube-based videos in learning daily English conversation. In the contrary, the one who have lack of motivation and attitude will see and think that learning English is extremely difficult. It will be most influential factor becoming obstacle for children in learning English.

In addition, to get better results, the other thing that affect learning process which come from the outside of learners is a learning atmosphere. The effectiveness in learning English using YouTube-based videos will be stronger if it is supported by an interactive learning atmosphere. This thing should be considered to achieve a stronger speaking English proficiency.

\section{Suggestions}

The researchers list up suggestions which are expected to be useful as follow: 1) For teachers, it is expected that the YouTube-based videos can be used as an alternative way of teaching to conduct speaking materials such as greetings and daily conversation. 2) For other researchers. The result of this research can be used as a foundation or a basis for further researches. It is hoped that the result of this research can be conducted better, and complete this research. 


\section{REFERENCES}

Asyar, R. 2012. Kreatif Mengembangkan Media Pembelajaran. Jakarta: Gaung Persada Jakarta Press.

Bickmore, T. 1999. "A Computational Model of Small Talk" Retrieved from https://mit.media.edu. Accessed on February $2^{\text {nd }}, 2020$.

Firdaus, Intan. 2017. "Penerapan Metode Montessori dalam Perkembangan Kemampuan Membaca dan Menulis Anak (Studi Kasus)". Pujangga Jurnal Bahasa dan Sastra. Vol 3, No 2. P 25-38. Jakarta.

Kemp, J.E. 1989. The Instructional Design Process. New York, US: Harper.

Krashen, S. D. 1982. Principles and practice in second language acquisition. UK: Pergamon Press.

Laver, J. 1975. “Communicative Functions of Phatic Communion”. In A. Kendon, R.M. Harris \& M.R. Key (Eds). Organization of Behavior in Face-to-Face Interaction: 215-238. Mouton.

Nuen, A.M. 2019. November 28). "Menyanggah Gagasan Penghapusan Pelajaran Bahasa Inggris di SMP-SMA" [Web log post].Retrieved from https://kompasiana.com. Accessed on February $2^{\text {nd }}, 2020$.

Mynard,Jo. 2011. "Learning Environment that Facilitate Reflection" in The Jalt Call Journal. Vol 7, No 3.

Nurfauziah, Erni. 2013. Penggunaan Teknik Talking Stick Dalam Meningkatkan Penguasaan Kosakata Bahasa Inggris Anak Usia Dini. Bandung: UPI Bandung.

Nurmawati. 2018. Implementation of Daily Conversation Method (DCM) to Improve Students' Speaking Ability at Ma'had Al Jamiah UIN Raden Intan Lampung. Lampung: UIN Raden Intan Lampung.

Panje, Marius, Sihkabuden, Toenlioe J.J, Anselmus. 2016. "Pengembangan Video Pembelajaran Bahasa Indonesia Teknik Membaca Puisi". Jurnal Teori Penelitian dan Pengembangan. Vol 1, No 8, P.1473-1478.

Richards, J.C. and Schmidt, R. 2002. Longman Dictionary of Language Teaching and Applied Linguistics 3rd Edition. London: Longman.

Riti, Jenita Angelina. 2014. Keefektifan Penggunaan Media Video dalam Pembelajaran Horverstehen Peseta Didik Kelas X SMAN Wates Kulon Progo. Yogyakarta: Universitas Negeri Yogyakarta. 
Jurnal Pujangga Volume 6, Nomor 1, Juni 2020

ISSN P 2443-1478

ISSN E 2443-148

Thornbury, S., \& Slade, D. 2006. Conversation: From Description to Pedagogy. Cambridge: Cambridge University Press.

Tucker, G.R. 1999. “A Global Perspective on Bilingualism and Bilingual Education”. Retrieved from https://cal.org. Accessed on February $2^{\text {nd }}, 2020$.

Widya, Tiarma Ika Yuliana, Yulia Sofiani. 2018. "Pengajaran Kosakata Bahasa Inggris dengan Media REALITA dan FLASHCARD”. Jurnal PKM: Pengabdian kepada Masyarakat Vol 01, No 01, P.39-47.

Wijaya, Asep. 2019. “6 Temuan Menarik Indeks Kecakapan Bahasa Inggris, Perempuan Lebih Jago" [Web log post]. Retrieved from https://idntimes.com. Accessed on February $2^{\text {nd }}$, 2020. 